\title{
Turismo e Excursionismo: o qualificativo rural : Um estudo das experiências e potencialidades no Norte Velho do Paraná
}

\author{
Tourism and Excursion: the rural qualifying adjective - A study \\ about the experiences and potentialities of the Old North Region of \\ Paraná, Brazil
}

Maria del Carmen Matilde Huertas Calvente *

Resumo

\begin{abstract}
Este estudo enfoca a diversificação contemporânea do turismo, na perspectiva da Geografia, tendo o turismo rural como tema central e como sub-temas a sua potencialidade, regulamentação, impactos e perspectivas. Entre as tendências atuais da prática social do turismo está a valorização da rusticidade e de paisagens naturais - as áreas rurais passam, portanto, a serem encaradas também como um território de suporte para as atividades de lazer. O turismo rural, no caso brasileiro, não possui um conceito já determinado, e na discussão do que é ou deve ser e na interrelação entre os vários agentes ligados à sua regulamentação algumas possibilidades são vislumbradas: a atividade pode servir para uma modernização que exclui grandes parcelas da população brasileira mas também pode ser encarada como uma maneira de incorporação destas pessoas nas transformações que a sociedade necessita. $\mathrm{O}$ texto resultante foi dividido em cinco partes: a diversificação do turismo enquanto um processo contemporâneo, investigando suas tendências atuais; as diferentes contribuições que servem à compreensão conceitual do tema principal e um levantamento dos problemas e benefícios relatados como possíveis; as diversas ações que influem no turismo rural, nas mais diversas escalas; os elementos da potencialidade; e um quadro do turismo rural na região estudada. O trabalho de investigação empírica abordou o desenvolvimento embrionário do turismo nas áreas rurais do Norte Velho do Paraná, Brasil, a partir das modalidades que estão surgindo, das experiências que seus protagonistas estão vivenciando e do perfil das pessoas que procuram o turismo rural como alternativa econômica e como visitantes. Através da necessária relação entre a abordagem teórica e empírica, há uma tentativa de contribuição para o conhecimento, entendimento e análise deste fenômeno cuja expansão é recente e, portanto, ainda pouco abordada pelos estudos geográficos.
\end{abstract}

Palavras-Chave: Turismo Rural; Diversificação; Potencialidade; Impactos - Norte Velho do Paraná

\footnotetext{
* Mestre e doutora na Universidade de São Paulo, Faculdade de Filosofia, Letras e Ciências Humanas; e Docente na graduação e pós-graduação: Desde mar/95, docente das disciplinas Epistemologia da Geografia, Geografia Humana Geral e do Brasil, Metodologia de Pesquisa em Geografia, Metodologia e Prática de Ensino em Geografia - Estágio Supervisionado, Epistemologia e Evolução da Geografia e Geografia e Turismo - Estudo do Meio. Pesquisa aprovada na Universidade Estadual de Londrina com o título O Turismo Rural no Norte do Paraná (1996 - 2001).fuscalve@uel.br
} 


\section{Abstract}

This study focuses the contemporary diversification of tourism under the Geography perspective, having the rural tourism as its main theme, and as sub-themes its potentiality, regulation, impacts and perspectives. Among the current trends of the social practices of tourism there is the valorization of rusticity and natural landscapes - the rural areas are, therefore, also considered appropriate for leisure. In Brazil, rural tourism does not have a predetermined concept. In the discussion of what it is or what is must be, in the interrelation among the several agents connected to its regulation, some possibilities are put into perspective: the activity can be a means to a modernization, which excludes large number of Brazilian population; on the other hand, it can be a way of integrating these people in the transformations the society needs. The final text was divided was divided into five parts: the diversification of tourism while a contemporary process, examining its current trends; the different contributions which support conceptual understanding of the main theme and survey of the problems and benefits; the different actions which have an influence on rural tourism; at different levels; the elements of potentiality; and a picture of the rural tourism in the studied region. The empirical survey dealt with the incipient development of tourism in the rural areas of Old North Region of Paraná, Brazil, based on the new trends, on the experiences carried out by their supporters as well as on the profile of the farm owners who are engaged with this activity as an economic alternative, or as visitors. Through the necessary relation between the theoretical and empirical approaches, there is an attempt to contribute to the knowledge, understanding and analysis of this expanding phenomenon, not yet thoroughly dealt with by geographical studies.

Key Words : Rural Tourism - Diversification - Potentiality - Impacts - Old North Region of Paraná, Brazil 